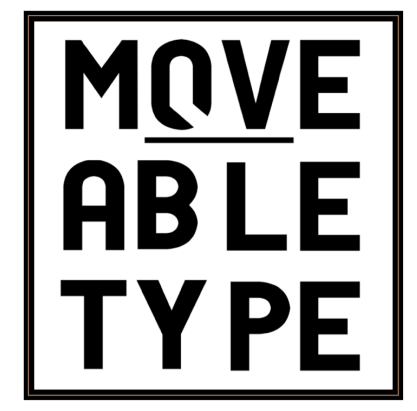

Framing the Painting: The Victorian "Picture Sonnet"

Author[s]: Leonée Ormond

Source: MoveableType, Vol. 2, 'The Mind's Eye' (2006)

DOI: $10.14324 / 111.1755-4527.012$

MoveableType is a Graduate, Peer-Reviewed Journal based in the Department of English at UCL.

(C) 2006 Leonée Ormond. This is an Open Access article distributed under the terms of the Creative Commons Attribution License (CC-BY) 4.0https://creativecommons.org/licenses/by/4.0/, which permits unrestricted use, distribution, and reproduction in any medium, provided the original author and source are credited.

\title{
UCLPRESS
}




\section{Framing the Painting: The Victorian "Picture Sonnet" Leonée Ormond}

During the Victorian period, the short poem which celebrates a single work of art became increasingly popular. Many, but not all, were sonnets, poems whose rectangular shape bears a satisfying similarity to that of a picture frame. The Italian or Petrarchan (rather than the Shakespearean) sonnet was the chosen form and many of the poems make dramatic use of the turn between the octet and sestet. I have chosen to restrict myself to sonnets or short poems which treat old master paintings, although there are numerous examples referring to contemporary art works. Some of these short "painter poems" are largely descriptive, evoking colour, design and structure through language. Others attempt to capture a more emotional or philosophical effect, concentrating on the response of the looker-on, usually the poet him or herself, or describing the emotion or inspiration of the painter or sculptor.

Some of the most famous nineteenth century poems on the world of art, like Browning's "Fra Lippo Lippi" or "Andrea del Sarto," run to greater length. There are, however, few long poems on a single identifiable work of art. "Fra Lippo Lippi," for example, leads up to Browning's account of "The Coronation of the Virgin," which hangs in the Uffizi Gallery, Florence, but the painting only appears in the closing stages of the poem.

Poems on paintings were not new to the nineteenth century, but the immediate origins of the Victorian "single painting poem" probably lie in the romantic period. One work which may have been influential was Shelley's "On the Medusa of Leonardo da Vinci, in the Florentine Gallery," the writing of which can be dated to October 1819. This dark painting of the severed head of Medusa, surrounded by snakes and other creatures, was given to Leonardo in the nineteenth century. The attribution has not stood the test of time, although the painting still hangs in the Tribuna of the Uffizi. Almost gothic in effect, the Medusa attracted Walter Pater, who must have known the Shelley poem and who describes the painting at length in his "Leonardo" essay, first published in 1869 and reprinted in The Renaissance. Both writers are attracted by what Shelley calls "the tempestuous loveliness of terror," the combination of death, writhing snakes and the head of a woman. Shelley's poem closes with a final reference to

A woman's countenance, with serpent locks, Gazing in death on heaven from those wet rocks. (250)

Shelley's "Medusa," in five eight-line stanzas, is obviously not a sonnet. Nor is another poem which may have influenced later writers of art poems, Keats' "Ode on a Grecian Urn." The Pre Raphaelite Brotherhood discovered the poems of Keats early in the history of their brotherhood, founded in 1848. From the evidence of their paintings, however, it was the historical narrative poems like "Isabella or the Pot of 
Basil" or "The Eve of St Agnes" which attracted them, not the Odes which became famous later in the nineteenth century and are so highly regarded in our time.[1] "The Ode on a Grecian Urn" has many of the qualities of the classic poem about a painting; it apostrophises its object as a historical survival, and it speculates on the eternal nature of human emotions, passionate love, exemplified by the couple on the urn, and the worship of beauty. The urn has lasted through time, and its continuing existence leads the poet to consider the transience of human life, a theme pursued by many later writers struggling to express their awe at the presence of a work of art completed hundreds of years before.

One of the first true "picture sonnets" was Wordsworth's "Upon the Sight of a Beautiful Picture, Painted by Sir G. H. Beaumont", composed in 1811 and published in 1815. The picture in question shows a boat becalmed at sea and a group of travellers in a wood. Wordsworth closes his poem with a reference to the theory of art's permanence, "Ars Longa, Vita Brevis":

Thou, with ambition modest yet sublime, Here, for the sight of mortal man, has given

To one brief moment caught from fleeting time

The appropriate calm of blest eternity. (Wordsworth 6)

Other painting sonnets by Wordsworth, like his "Upon the Sight of a Beautiful Picture," are tributes to contemporary works. A second example marks the departure to Cambridge of Wordsworth's own portrait by Henry Pickersgill, and a third centres on a portrait of the Duke of Wellington at Waterloo, by Benjamin Robert Haydon. What must be among the earliest old master picture sonnets in English poetry comes from a group written after Wordsworth's tour of Italy in 1837, a year which also saw the accession of Queen Victoria. This is "Before the Picture of the Baptist, by Raphael, in the Gallery at Florence." Wordsworth's Raphael sonnet celebrates the painter who was regarded as supreme throughout most of the Victorian period, but says very little about the picture which shows the young St John, arm raised, setting out on his mission. Instead, Wordsworth reminds us of John"s words, adapted from the four gospels: "Make straight a highway for the Lord --- repent!"[2]

The most influential poet of art sonnets was Dante Gabriel Rossetti and it is not hard to see why he chose this form. In England the sonnet is associated with Shakespeare, but for Rossetti, the son of an Italian professor at King's College, London, the Petrarchan or Italian sonnet was an obvious choice, and he used it extensively throughout his career, even rendering sonnets by Dante, Guido Cavalcanti and Cino da Pistoia into English versions.

The practice of writing sonnets to accompany his own paintings (and often placing them on the frame) apparently began with Mary's Girlhood, one of his earliest works, for which he wrote a double sonnet in 1849. The philosophy of the PreRaphaelite Brotherhood owed a considerable debt to Rossetti's determination to 
bring together the practice of literature and the practice of the fine arts. The preface to the Brotherhood's magazine, The Germ, declares, "With a view to obtain the thoughts of Artists, upon Nature as evolved in Art, in another language besides their own proper one, this Periodical has been established" (Rose xxvii).

Rossetti began to write sonnets for paintings by other artists at around the time of his visit to Paris and Belgium with William Holman Hunt in 1851. The two young men visited the Louvre in Paris and Rossetti's response, expressed in sonnets drafted either in the museum or very soon afterwards, was one of predictable dismay and disgust. Pre-Raphaelitism by its very name espoused the principles of early Italian art and disparaged the art that followed. Rossetti's sonnet, "Last visit to the Louvre," reflects his loathing for the abundant works by Peter Paul Rubens, and by other detested painters like Correggio and Claude Lorraine:

dear God! The flesh Thou madest smooth

These carked and fretted, that it seemed to run

With ulcers; and the daylight of thy sun

They parcelled into blots and glares, uncouth

With stagnant grouts of paint. (Collected Poetry 352)

Paintings by Leonardo da Vinci, including the Mona Lisa, not yet an iconic work, made a more favourable impression. Rossetti was not unfamiliar with Leonardo, and had written a sonnet on the Virgin of the Rocks, (now in the National Gallery but in the Earl of Suffolk's collection) before leaving London. In the Louvre he saw another version of the subject. Rossetti'sdark sonnet, with its questions about the incarnation, its stress on ideas of death, and its evocation of the rocky setting behind the figures, was not published until 1870 and it has been suggested that he revised it after he reading Pater"s essay in The Renaissance (Rossetti Collected Writings 488).

Another of Rossetti's Louvre sonnets was inspired by the Concert Champêtre, or, as Rossetti calls it, "Venetian Pastoral", then attributed to Giorgione, but now thought to be the work of Titian. Rossetti found it: "so intensely fine that I condescended to sit down before it and write a sonnet" (Fredeman 1:40). The poem was published in the Pre-Raphaelite magazine, The Germ, and then re-issued, in a revised form, in the 1870 volume of Rossetti's poems. In both versions, Rossetti conveys the sense of heat and drowsiness which he found in the painting, before, characteristically, focusing on one female figure, that of the girl with a pipe seen from behind on the right. In the same volume of The Germ, Rossetti published another Louvre sonnet, "For an Allegorical Dance of Women by Andrea Mantegna (in the Louvre)." This is Mantegna's Mars and Venus, sometimes known as Parnassus. Here, characteristically, Rossetti picks out particular features of the work, in this case the background and the women dancers. He also ponders the painter's own response to his subject. Did Mantegna paint it in an inspired trance? 


\section{Scarcely, I think; yet it indeed may be \\ The meaning reached him, when this music rang \\ Clear through his frame, a sweet possessive pang, And he beheld these rocks and that ridged sea.}

The sonnet concludes with a statement of the primacy of the heart over the mind:

It's meaning filleth it,

A secret of the wells of Life: to wit:-

The heart's each pulse shall keep the sense it had

With all, though the mind's labour run to nought. (Collected Poetry 184)

As he approached Belgium on his journey of 1851, Rossetti anticipated with pleasure the opportunity to see the work of the early Flemish master, Jan Van Eyck. The Van Eyck brothers fitted into a Pre-Raphaelite agenda, because their work is comparable to that of the early Italian artists whom the Pre-Raphaelites (at least nominally) admired. The Brotherhood were familiar with Jan Van Eyck's Arnolfini Marriage Portrait in the National Gallery, a work echoed in some of their own paintings. Rossetti and Hunt saw a number of works by the Van Eycks on their journey, and, according to Hunt, Rossetti began to write on the famous Adoration of the Lamb altarpiece in Ghent Cathedral in Ghent.

The real surprise and excitement of the Belgian visit, however, was the discovery of an artist of a generation later than the Van Eycks, Hans Memling or Memlinc (14351494). Memling was, Rossetti decided, more "poetical" than Van Eyck (Fredeman 1:128). It was in Bruges, at the Academy of Fine Arts and in the Hospital of St John, that Hunt and Rossetti saw paintings by Memling. His St John triptych still stood at the Hospital high altar for which it was painted. Writing home to his brother, Rossetti told of his response to the "glory of colour, and above all the pure religious sentiment \& ecstatic poetry of these works" (Fredeman 1:128).

Rossetti's sonnet on the St John altarpiece is largely taken up with the central panel and with St Catherine of Alexandria who, resplendent in black and gold, kneels to the right of the Madonna and child. Rossetti tells us a little about the appearance of the painting (the Virgin Mary is reading, and the two patron saints of the Hospital "listen and watch"), but his attention is held by the figure of Catherine, utterly joyful as her "hushed and mild" life, "Laid in God"s knowledge" is "fitly" rewarded by her mystic marriage with the infant Christ (Collected Poetry 345).

Rossetti continued to write sonnets for his own paintings, but there are few significant old master sonnets from his later period. The most important of these was inspired by his discovery of Sandro Botticelli, then little-known in Britain. In 1867, Rossetti bought a Botticelli from Christies for $£ 20$. In a note to his sonnet, "For Spring, by Sandro Botticelli in the Accademia of Florence," he identified the sitter in his own painting as the model for Flora in Botticelli's masterpiece (191). Rossetti 
was way ahead of contemporary taste in buying the painting, but, by the time that the poem was written in 1880, Botticelli was "all the rage," in part because of Walter Pater's essay of 1870 . However, with its emphasis on the "wind-withered New Year" and on "Dead Springs," Rossetti's poem is scarcely a celebration of Botticelli's Primavera (191).

Anyone choosing the sonnet form for a poem on paintings would certainly have felt the influence of Rossetti. Among those who followed his example was William Cox Bennett, a minor poet, eight years older than Rossetti and an acquaintance of his. Bennett was involved in local politics, but also worked as a leader writer and art critic for the London Figaro. He published a number of sonnets on art, including classical statues seen in Italy and paintings in London galleries. One sonnet, dated to 1860, is devoted to Guido Reni's Saint Sebastian in the Dulwich Picture Gallery, another to Murillo's Holy Family in the National Gallery. Murillo was a particular favourite with Bennett, who seems never to have travelled to Spain, but wrote sonnets on his pictures in the National Gallery, the Louvre and the Picture Gallery at Dulwich. The titles of Bennett's sonnets often include the word "before," making clear his presence in front of the work of art. Like Rossetti and Wordsworth before him, Bennett is careful to detail the gallery in which the picture or the sculpture is to be found, thus establishing the authenticity of his experience. Like Shakespeare, Bennett reminds us of the passage of time:

'We are such things as dreams are made of;' - yes, Friends, seem we not as breathings upon glass.

Bennett gives his readers few details of the paintings which he apostrophises. In the same sonnet, "In London - at the National Gallery - before Murillo's 'Holy Family,"' he could be looking at any great work of art, as he concludes:

These radiant ones are of eternity; We are the shadows; they, realities. (498)

Of the Murillo flower girl at Dulwich, he writes with more precise detail:

So smiled she in the hour in which he drew

This gladness for us; so still smiles she now.

That laugh that then he gave her does not bow

To time or death, immortal, ever new. (Bennett 509)

Many poets who followed Rossetti in the tradition of the painter poem fell into what might broadly be called "aestheticism," like him they admired early Italian, German or Flemish art. Bennett's chosen subjects on the other hand, Guido Reni and Murillo, for example, are closer to the taste of an earlier generation. 
A quarter of a century younger than Bennett was Eugene Lee Hamilton, betterknown today as the half brother of the critic Vernon Lee than as a poet in his own right. Lee Hamilton, like Vernon Lee, spent much of his life living In Italy. It is not surprising therefore that he wrote sonnets (his usual form) about the paintings in Italian galleries. What is more surprising is that Lee Hamilton was bed-ridden for a large part of his writing life, with an illness which may have been psychosomatic. A group of his painting poems were put together into a group with the title "Brush and Chisel," twelve sonnets gathered into a volume entitled Sonnets of the Wingless Hours of 1894. Like Rossetti, Hamilton uses an Italian sonnet form with a clearly marked division between the octet, made up of two four line stanzas, abba, abba and the sestet, made up of two three line stanzas, cde cde. These are fourteen line poems, but, because of the spaces between the sections, they do not look like sonnets on the page. For his painting sonnets Lee Hamilton turned to a varied range of subjects. Like Shelley and Walter Pater, he writes of the so-called

Leonardo Medusa, and, like them, he takes the occasion to concentrate on ideas of death. The snakes try to escape the once sheltering head, but nevertheless die together with Medusa. One sonnet is on a Gustave Dore illustration to Dante, and others take their subjects from sculpture, the Venus de Milo in the Louvre, a torso of Venus taken out of the sea at Tripoli Vecchio. Here and elsewhere, Lee Hamilton ponders those concepts of immortality through the art-work which had fascinated Keats and his successors. In the second sonnet of a trio called "The Ever Young," he declares that the Venus de Milo, like Titian's Magdalen, will never be old. In the sestet, he turns to literary comparisons and says the same of Shakespeare's Juliet and of Browning's Pompilia in the Ring and the Book. However, the third sonnet of the group reverses the familiar position and raises questions of conservation which would have been familiar to those living in Italy:

And yet Art's wonders are at last Death's prize:

The shattered marble crumbles into lime;

Canvas and Fresco perish under grime;

The pen"s great shapes will die when language dies.

The Milo stone will go where lime"s dust flies,

And Titian"s Magdalen turn black with time. (34)

Art objects, he declares, are vulnerable, and even literature will have no meaning if the language itself should die.

At least one of Lee Hamilton's poems on single works of art was inspired by a painting which Rossetti is unlikely to have admired, Raphael's Archangel Michael in the Louvre. For Lee Hamilton, the Archangel, springing out of a "crocus-coloured morn" with his "diamond spear," is like a "flame." Michael is a being of light where Satan is dark with a "rayless head." Hamilton certainly tells us something about the appearance of the picture, with its background scene of "earth's bare plain" behind the figures: but, like others, he draws a moral conclusion in the sestet: 
So leaps within the soul on Wrong or Lust

The warrior Angel whom we deem not near,

And rolls the rebel impulse in the dust,

Scathing its neck with his triumphal tread,

And holding high his bright coercing spear

Above its inexterminable head. (35)

Hamilton gives a closer description of the horror of the scene represented before him in writing of Luca Signorelli's frescoes of The Last Judgement, in the Cathedral at Orvieto. In a pair of sonnets, "The Rising of the Dead" and "The Binding of the Lost," the dead struggle into the light through "earth's thin crust," "as yet too numb to dread" (36). Hamilton tells in the second sonnet of the damned and of the devils who take them away:

While, through the thickness of the lurid air,
The flying fiends, from some far unseen vent,
Bring on their bat-wing'd backs, in swift descent,
The souls who swell the waiting myriads there. (37)

In general, poets wrote about paintings or sculptures which they admired, but, in two sonnets on Mantegna's Judith drawing in the Uffizi, Hamilton takes a far more critical approach, arguing that Judith, when killing the giant Holofernes, would not have been as Mantegna represents her. Mantegna's Jewish heroine is a "stony, bloodless Judith" "whose benumb'd hands hold/ A stony head and an unbloody blade" (43). Was the artist, the poet asks, afraid to paint what he knew well by sight, the Judiths in the Italian streets or the heads placed in the square after executions. The sestet of the first sonnet argues that the real Judith would have been very different, a warrior woman, "like some dumb tigress" (43). In these sonnets, there is little attention to the appearance of the Mantegna drawing, Lee Hamilton is concerned only with realism. In the second poem, he speculates that the scene of the murder would have been full of flashes of light, of the gleam of jewels and of reflections in Holofernes' armour. Hamilton's giant, as opposed to Mantegna's, becomes a threatening sexual monster with "red lascivious lips" and a "curled and scented beard" (44).

Painter poems had a particular appeal for women poets. Among them were Emily Pfeiffer, a year older than Rossetti, and Michael Field, the pen name of two poets who wrote together, aunt and niece, Katharine Harris Bradley and Edith Emma Cooper. Pfeiffer, best known now for her long poem on a fallen woman, "From Out of the Night," included some art sonnets in a volume published in 1888. Among these are two sonnets on Fra Angelico paintings at the Monastery of San Marco in Florence. Pfeiffer's title places the poet herself in the gallery "In face of the picture of the radiant Madonna and Child, by Fra Angelico, in his cell at San Marco" (Pfeiffer 24).[3] In a pair of contrasting poems, "Joy of Joys" and "Sorrow of Sorrows," she concentrates on the figure of the Virgin Mary as she is represented in two paintings. 
The first is the Madonna and Child in Fra Angelico's own cell at San Marco, the second is the figure of the Mater Doloroso in the great painting of theCrucifixion in the Chapter House. The hands of the Madonna are one focal point of both poems, "bound" "in lasting service" in the "Joy" sonnet, "bare" in "Sorrow" (24-25).

The Crucifixion is mentioned in George Eliot"s Romola, but the novelist was prevented from going upstairs to see the other Fra Angelico paintings by the ban on women entering the monastery, and she had to rely upon George Henry Lewes for information about them. The rules had clearly been relaxed by the time of Pfeiffer's visit.

Michael Field's Sight and Sound of 1892 is one of the most complete attempts to render art into poetry. The poems recall the authors' journeys on the continent, as well as their visits to the National Gallery in London and to private collections in Britain. The preface tells us that: "The aim of this little volume is, as far as may be, to translate into verse what the lines and colours of certain chosen pictures sing in themselves; to express not so much what these pictures are to the poet, but rather what poetry they objectively incarnate" (v). The subjects range fairly widely, but are recognisably "aesthetic," befitting writers who were friends, not only of Robert Browning, but also of Oscar Wilde, Algernon Swinburne and W.B.Yeats. Predictably, there is a poem on Leonardo"s Mona Lisa, four on Botticelli and four on Correggio. A newer entry to the charts of popular painters was Watteau, and poems on his paintings come first and last in the volume with a third, on his Fête Champêtre, in the middle. Only four of the poems in the volume are true sonnets, but two are "almost" sonnets. One of these, the poem on Mona Lisa, is of only 11 lines, while the other, on "A Pen Drawing of Leda by Sodoma in Weimar," has 14 lines but in a line structure which differs from the classic sonnet, with its markedly long and short lines. Two of the "true" sonnets are on a painting by a less famous artist, Bartolommeo Veneto, and his St Katharine of Alexandria in the Städel Institute in Frankfurt. In Field's volume these two sonnets stand next to another poem (not a sonnet) on a work by the same artist and in the same gallery, "A Portrait." In this, it must be admitted, far more fascinating poem, the two poets speculate on the portrait of a young woman swathed in white and holding wild flowers. To them it seems clear that she is a courtesan and they construct a narrative of her decision to have herself painted, and of her choosing the flowers which she holds as she picks them in the fields.

Michael Field's "St Katharine" sonnets tell of another female subject. Field describes how the saint touches the spokes of the wheel, the symbol of her martyrdom. As in the "Portrait" and so many other poems on painting, the sonnet ponders the eternal nature of the image. The last words of "A Portrait" are "Lo, she has conquered death!" (30) and the "St Katharine" poem gives us another reminder of the passage of time. The saint had been dead for a thousand years before Bartolommeo painted her, shrinking from the pain, like one dead rather than living, her "pure, gold cheeks are blanched" (31). Deliberately turning from this image of a violent death, the viewer's eye is taken back towards the bay-tree behind the saint and then to an 
open landscape. The scene is evoked with a life and movement not found in the poem's account of the central figure. Several critics have commented on the sensuality of Field's poems. Here, however, for all the shrinking of the saint and the apparent sweat of fear and pain which flattens her yellow hair, the final couplet carries us out of the painting to the "swift shallop" (31) in the background.

Michael Field was clearly fascinated by Botticelli's Primavera. Here the poets took up a subject previously treated by Rossetti, and, like him, they found the painting disturbing and bleak. There are three works on the picture in their volume, a pair of sonnets and a longer poem. The first of the two sonnets, "The Figure of Venus in 'Spring'" is largely descriptive, although Venus is presented as a sentient and thoughtful figure. Is love, the poem asks, a bitter thing and a blight:

Brings love in truth a bitterness to blight

The yet unstricken gladness of the year?

If the first sonnet asks one question, the second asks another, continuing the dialogue:

Or is it Destiny that doth compel

Her hand to stay its blessing?

Are the three flowerless young women in the painting dancing together on their way to hell, guided by Hermes who stands, about to cut the orange from the bough? The poets do not answer the question.

If the short poem on a painting is in many ways a late nineteenth century form, there are some fine twentieth century examples. W.H. Auden's "Museé des Beaux Arts" has some, at least, of the marks of the earlier genre. Like all of the poets mentioned here, he tells us the name of the art gallery, although he saves the name of the painting, Jan Breughel's Icarus, until later in the poem. Auden's "take" on the painting, however, is very different from that of Rossetti, Lee Hamilton or Michael Field. Like them, he comments on the picture's age, and on its message for the poet in the present, but this is a message appropriate to years of war and disaster in Europe. The "old masters," Auden says, are "never wrong" about "suffering." As Icarus crashes into the water:

the sun shone

As it had to on the white legs disappearing into the green

Water; and the expensive delicate ship that must have seen

Something amazing, a boy falling out of the sky,

Had somewhere to get to and sailed calmly on. (19)

Where the earlier poets remind us of their presence in front of the work of art, Auden's poem is distinguished by its detachment. Looking at a painting has 
suggested to him (as with many before him) a parallel with contemporary human life, perhaps with reference to the current debate on appeasement. Although Rossetti denied the possibility of working with the "head" in "An Allegorical Dance of Women," here the "mind's labour," far from producing "nought," has resulted in a poem.

\section{Works Cited}

Auden, W. H. Collected Shorter Poems. London: Faber, 1950.

Bennett, William C. Poems. London: Routledge, 1862.

Field, Michael. Sight and Sound with Underneath the Bough. Oxford: Woodstock Books, 1993.

Fredeman, W. E., ed. The Correspondence of D. G. Rossetti. 4 vols. Woodbridge, Suffolk: Boydell and Brewer, 2002.

Hamilton, Eugene Lee. Sonnets of the Wingless Hours. Portland, ME: Thomas B. Mosher, 1908.

Pfeiffer, Emily. Sonnets. London: Field and Tuer, 1886.

Rose, Andrea, ed. The Germ. Oxford: Birmingham Museums and Art Gallery, 1984.

Rossetti, Dante Gabriel. Collected Poetry and Prose. Ed. Jerome McGann. London: Yale UP, 2003.

Rossetti, Dante Gabriel. Collected Writings. Ed. Jan Marsh. London: Dent, 1999.

Shelley, P. B. The Works of P. B. Shelley. Ed. Mary Shelley. London: Edward Moxon \& Co., 1847.

Wordsworth, William. The Poetical Works of William Wordsworth. Ed. E. De Selincourt and Helen Darbishire. Oxford: Clarendon Press, 1946.

[1] I would like to record my thanks to Dr Sarah Wootton for her help in establishing the nineteenth century reputation of the "Ode on a Grecian Urn."

[2] Other sonnets in this sequence are translations by Wordsworth from the poems of Michaelangelo. 
[3] I am grateful to Christine Hanges for pointing out these poems to me. 